\title{
The Millennium Development Goals: A missed opportunity?
}

\section{WENDY HARCOURT}

Nowadays within the United Nations system, the Millennium Development Goals (MDGs) (see box) are mentioned everywhere you turn. Outside the system, they are discussed far less, and surveys indicate that they are not widely known and if known most people are cynical rather than appreciative. Some see them as simply hijacking space and pulling in good people, particularly eloquent speakers from the South, into yet another UN project. Somewhat more puzzling however, is that even senior UN staff call them publicly the minimum development goals and almost all commentators, including those responsible for making them happen, see them as likely to fail. Is there, one wonders, something wrong with the 'messaging'? What are some of the reasons for this anticipated 'failure' when we are just a few years into the process and have another decade to go?

The first observation is that the goals themselves are not so lofty or impossible or new. And so, one has to conclude that despite all the technical talk about strategies, indicators and measurement and the estimates of funds required, all presented in an impressive array of tables and reports, essentially the MDG process is a political one - both within the UN and outside. It seems that Kofi Annan is taking the occasion to call the house to order in order to sharpen the perceived success rates of the UN. As the organization is ever more under public scrutiny, he has to show it works even in relation to the failures of governments to keep promises. He needs to weather the general mood swings to private-public partnerships, "corporate responsibility', a tightening of state funds and a strong 'conference fatigue'. Big UN events and promises, so the story goes, waste a lot of money and do nothing to end poverty or prevent HIV/AIDS or limit environmental degradation or halt the widening gap between the rich and the poor. In short, in an era of neo-conservatism the UN is struggling to survive attacks from all sides. No doubt even more since the US election in November 2004 and a second round for an administration that sees itself with the mandate to pursue unilateralism and to dominate the global scene, secure in its military and economic might. Certainly, it seems set to undermine even further multilateral agreements on international justice, the environment and women's reproductive health and rights. 
The MDGs seem somewhat tame in this picture. They do, however, represent a strong push from Annan to pull the UN system behind a 'do-able' set of goals agreed to by Heads of State at the Millennium Summit in 2000 and Monterrey in 2002 and put in place by all the Governments who signed. This global process will be steered by expert advice to the UN secretary general (led by Jeffrey Sachs at Columbia University) and flanked by a UNDP run campaign to reach civil society and parliamentarians and a national monitoring reporting process by national governments of the operational success. They distil the many and complex issues of the 1990s 'decade of UN Conferences' into eight marketable goals with 48 indicators to measure the success. By reaching the goals, the UN will show it can succeed 'on the ground'. With the MDGs, the UN has identified the key issues and knows the figures, so all it needs to do now is raise the funds through rich countries and then through a not so expensive process systematically improve life for millions (the overall goal to half global poverty), and at the same time, reorder the UN behind a process that gives it meaning and shows its critics that it works.

One can understand why it is already set for failure. It seems that the MDG process is taking a technocratic, if not bureaucratic, approach to an infinitely complex world. It seems to be leaving the negotiating of politics to others or at best to the UN corridors while relying on 'campaigns' and 'experts' to calculate the figures and then sell the strategies to governments and civil society. This is, after all, an oft-tried and failed top-down approach. To begin with, even the overall goal to 'halve global poverty'as any person working for social justice will tell you begs the question of what happens to the other half. Should they just continue in poverty? So which half do we go for? And, of course, global poverty is not the same as halving poverty in each country. What kind of poverty are we talking about? How can figures and targets capture all that is needed to provide for a person's well-being? And when we move into the individual goals there are even more questions. How can education be the only measure of women's empowerment? What happened to reproductive health and
AIDS, surely there are foundations and agencies which are doing much tougher and necessary work? Any how, what about health system reforms? What happened to the human rights approach that was so strongly pushed in UN Conferences and in the Millennium Declaration?

Moving beyond these questions - there are many more raised in the journal articles - the real concern is the political process of how the MDGs were framed and are now being proposed. At a micro-level, neither there is little accountability or transparency nor a sense of global responsibility. Why are national reports for the South insisted upon for all targets and for the North only for Goal 8 (on partnership and development cooperation)? Why and how are all these calculations on the funding required being made? Who is doing the measuring? What is the constituency of the Millennium Project? Have we forgotten the highly questioned role of Jeffrey Sachs in Eastern Europe? How do the four branches of the process relate to each other? How does the Project relate to the Campaign to the National Reports to UNDP? Where are the clear spaces for civil society not only to be consulted but also to help design the strategies? Why is the five-year review proposing that civil society meet before and not during the Heads of State Summit? How do the PRSPs set by the World Bank relate to the MDGs?

Many if not all these questions can be answered 'behind' the scenes by UN staff, members of the project, the campaign, involved NGOs, members of governments and engaged parliamentarians. But officially there is no questioning, and there is no political agenda; the international community is expected, as the UN staff were expected, to accept the MDGs as the next 15 years of international development effort.

In the light of neo-conservative agendas and the threat of unilateralism, I would argue that there is much more that needs to be done at the macrolevel by the international community. A major reason why the MDGs will fail is not because the funds will not be allocated, nor that the measuring and monitoring is questionable, nor the impractical approach of having four different almost separate strands in the UN responsible for the MDGs. We can all see beyond the rhetoric - some 
of which is repeated critically and uncritically in this journal issue - that the MDG process will find the money, receive the backing of governments and harness public support to reach the goals. We all know there are different power interests within the UN that have to be satisfied. Indeed in all the debates around the MDGs, it is hard to remember that the $\mathrm{UN}$ is meant to take an operational role to support intergovernmental processes rather than stride out with its own vision and ways of working. Achieving the MDGs is obviously not the primary responsibility of the UN. Their achievement is first and foremost the responsibility of the governments who made commitments at the round of the UN Conferences. The role of the UN is to generate political will and commitment, and create mechanisms through which governments are made accountable to other governments. This is a highly political process. Not so many are deluded into thinking the MDGs are the answer to the world's poverty, social and economic inequality. It seems fair to say that realistically the MDGs are a tool that could be useful at the national level to shift public funding towards human development aims, or to promote North-South solidarity in the richer countries at the global level and to keep the UN ticking over. However, they are clearly a side show to main world events, they are neither tackling systemic problems nor engaging a broad audience in our US-dominated war-ridden and fearful world.

The real issue is not the geopolitical one, it is on the ground politics where the MDGs are missing a major opportunity because they follow this topdown bureaucratic and technocratic formula. There is a potential audience for a UN-led process to end poverty. It is perhaps not too late to challenge the MDG process, particularly given the sense of failure and cynicism that pervades, as many of the articles in the issue show. If the MDGs are a process to set an agenda and mobilize actors behind it, who are the UN mobilizing? It seems from many of the articles that the UN can mobilize 'a-political' technical expertise, to some extent funds, but not much more. The UN cannot impose its agenda on key actors who are at the centre of main world events and they are struggling to gal- vanize the kind of on the ground political process that would be necessary to achieve the MDGs. The game the UN plays, and has always been playing, is government-to-government accountability. This game does not work anymore against neocon unilateralists, nor does it work when the key issue is the accountability of governments to their own people. The MDGs could be a good occasion for the UN to try to break away from its highly limiting government-to-government game, notably by trying to link up seriously with civil society. But this is not happening - and if it does not happen, the UN will have missed a chance to reinvent itself through the MDG process.

UN officials leading the MDG processes are simply not listening to what and where people are becoming excited and engaged. Meetings on the MDGs are not standing room only (unless the ticket and lunch is paid). But people are mobilizing around calls to reclaim the UN, rallies for peace and social forums in all regions of the world as part of the search for global and social and economic justice. Where do the MDGs fit into that schema? How can all that energy and goodwill be harnessed in ways that will transform the MDGs from a dry technical set of bureaucratic strategies that pretend to be above politics into an open democratic process? Can the MDGs thrive on dialogue, new visions and ideas in order to find new financial resources and methodologies, and thereby help contribute to a new politics that reflects the needs of 'we the people' today?

Recently, I was at a meeting in Padua, Italy, in a standing room only meeting of 600 people from all walks of life who were debating on how to reclaim the UN as part of the World Social Forum process. The few UN people there - those responsible for civil society - were two sorts, either those who were on their way out and spoke somewhat in despair about how they joined the UN to make a better world and then became locked into bureaucracy. (Mind you, it was clear that such a sad statement could never be said publicly, only in memoirs.) Or the other sort, fresh faced, who dutifully delivered the speech, looked around for the 'known' NGOs who 'should have been there' (but were not) and exited to take the next plane. In both cases they were not engaged in the 
discussions but were weary on-lookers. Neither type planned to go to the Social Forum. They saw themselves as not wanted, strange given that the planned discussion was all about the UN system and certainly contradictory to the spirit of peoples' forums where you take ownership rather than wait for invitations. They were, of course, full of corridor talk about the MDGs and how they wouldn't work. Why, I wondered, couldn't we bring all the excitement and hope that the 'Peace Table' meeting offered into the halls of the UN and debate with officialdom as well as among the people? I suspect I was participating in just one of hundreds of events that will be happening in the next years - 150 groups requested to organize meetings on reforming the UN at the World Social Forum in January 2005. The MDG process needs to build on this constituency and make the process politically relevant if it is to work.

In volume 48 of Development, we contribute to that process with a series of articles on the MDGs from those who are integral to the process, within and outside the UN. In the following issues of this volume, we will take the readers into political arenas where civil society is a much less reluctant partner. Nicola Bullard will be guest editor for an issue on the 'Movement of Movements', following up the different movements' expectations and vision for change within the World Social Forum process. We will then look at global violence and the so-called failed state, with a critical examination of the reconstruction process in the post-conflict period - what happens in the name of development, peace and democracy. Lastly, we will look at conflicts over natural resources - some of the most contested and unexamined areas of local development today. Throughout the volume in the Dialogue section, we will be debating alternatives - beginning with a self-reflective piece in this issue by David C. Korten. I hope readers agree that it promises to be an exciting and challenging volume.

\section{Millennium Development Goals:}

1. Eradicate extreme poverty and hunger

2. Achieve universal primary education

3. Promote gender equality and empower women

4. Reduce child mortality

5. Improve maternal health

6. Combat HIVIAIDS, malaria, and other diseases

7. Ensure environmental sustainability

8. Develop a global partnership for development

For the complete listing of the goals, targets, and indicators for MDGs see http://www.un.org/millenniumgoals/ 